\author{
Andrzej T. Gruchot \\ dr inż. \\ Uniwersytet Rolniczy w Krakowie, \\ Katedra Inżynierii Wodnej i Geotechniki \\ rmgrucho@cyf-kr.edu.pl

\section{Eugeniusz Zawisza} \\ dr hab. inż., prof. UR \\ Katedra Inżynierii Wodnej i Geotechniki, \\ Wydział Inżynierii Środowiska i Geodezji, \\ Uniwersytet Rolniczy im Hugona Kołłątaja w Krakowie \\ kiwig@ur.krakow.pl
}

\section{Tymoteusz Zydroń}

dr inż.

Uniwersytet Rolniczy w Krakowie,

Katedra Inżynierii Wodnej i Geotechniki

t.zydron@ur.krakow.pl

\section{Ewa Klimek}

mgr inż.

Absolwentka Akademii Rolniczej

w Krakowie

DOI: 10.35117/A_ENG_17_05_03

\title{
The impact of a test method on the liquid limit of the selected cohesive soils
}

\begin{abstract}
The research presented in this paper aimed at the determination of the impact of a test method on the liquid limit of the selected cohesive soils with different content of clay fraction: loosely cohesive - clayey medium sand, moderately cohesive on the border of loosely cohesive - coarse silt and firmly cohesive - silty clay. Liquid limit was determined by the following methods: Casagrande, Vasiliev and the cone penetrometer. It was stated, that the values of the liquid limit of the tested soils determined by various methods were different, which significantly affected the assessment of their plasticity and consistency. According to the standard PKN-CEN ISO/TS 17892-2:2009, the liquid limit should be determined with the cone penetrometer, whereas the alternative is Casagrande's method. The conducted tests showed, that in the case of cohesive soils containing up to $10-11 \%$ of clay fraction, the differences between the values of the liquid limit determined with the cone penetrometer and the Casagrande's method were relatively small and equaled $1-2 \%$, therefore both methods are correct. In the case of cohesive soils containing more than $20 \%$ of clay fraction, differences between the values of the liquid limit determined with the cone penetrometer and the Casagrande's method were slightly higher than in the previous case, and equaled approximately $4 \%$. In those cases, determination of the liquid limit can be performed both using the first or the second method, though the above-cited standard recommends the cone penetrometer method.
\end{abstract}

Keywords: Cohesive soils; Liquid limit; Cone penetrometer; Casagrande apparatus 


\section{Introduction}

The concept of consistency and the state of plasticity were introduced. Plasticity is called the ability of the soil to undergo permanent (irreversible) deformation at constant volume without cracks and crumbling. This feature only shows the land that contains particles composed of clay minerals in its composition. By increasing the water content of cohesive soils, the transition from compact consistency through the plastic to liquid occurs. According to the consistency intervals, the limits of shrinkage, plasticity, and fluidity are different. The consistency limits are largely dependent on the composition of the grading and mineralogical soil, its cohesiveness, the shape and elastic properties of the mineral particles, and the structure of the soil [3], [7] and their values also depend on the test method employed and the experience of the person performing the assay. The liquidity limit is most closely related to the granulometric composition of the soil and, in particular, to the content of the clay fraction. Wiłun [15] stated that the more soil contains the clay fraction, the greater the possibility of adsorbing water, and the higher the value reaches the limit of liquidity. The mineral composition of the soil also greatly influences their plasticity, because different minerals with uneven intensity interact with water. In addition, the shape of the particles depends on the crystal structure of the minerals, which in turn affects the plasticity. There is no close connection between the yield strength and the granulometric composition. Grounds of $2-3 \mu \mathrm{m}$ in diameter are hard plastic, having a particle size of $2-1 \mu \mathrm{m}$ have a small plasticity. The plasticity of the soils with a particle size of $1-0,5 \mu \mathrm{m}$ is already considerable and reaches the greatest values at diameters less than $0,2 \mu \mathrm{m}[4]$.

The boundaries of consistency belong to the basic physical parameters of cohesive soils, used in engineering practice [6]. Therefore, it is important to use appropriate methods of identification. The most difficult to determine is the correct determination of the liquidity limit.

The aim of the study was to determine the impact of the test method on the value of the liquidity limit and consequently on the plasticity index, ie the assessment of consistency of the cohesive soil.

\section{Materials and methods of research}

The study was conducted on three cohesive soils with different content of loam fraction. These were the land: small-dense - sandy loam from the foundation excavation at the Piaski Wielkie estate in Krakow, a middle-sized man on the border of the medium-dense - thick dust from the unveiling of the slope in the Zwierzyniec district in Krakow and concise-dense from the excavations on the site of the Racibórz reservoir Bukowie nad Odrą [5].

The basic characteristics and standards of soil compaction were determined using standard methods. The granulometric composition is a sieve method for $\mathrm{d}<0,063 \mathrm{~mm}$ and isometric for $\mathrm{d} \leq 0,063 \mathrm{~mm}$ and the density of the measurement. Optimum humidity and efficient measurement performance in the $1.0 \mathrm{dm}^{3}$ system with compaction energy $0,59 \mathrm{~J} \cdot \mathrm{cm}^{3}$.

The plasticity limit was determined by the roller method. The liquidity limit was determined using Casagrande`s, Wasiliev's method using a cone with a tip angle of $30^{\circ}$ and a weight of $76 \mathrm{~g}$, a cone penetrator with a cone angle of $30^{\circ}$ and a weight of $80 \mathrm{~g}$, according to standard procedures in accordance with [10].

The Vasiliev and the cone penetrometer methods are based on the measurement of cone depression, in this case with a corner angle of $30^{\circ}$ into a ground paste. In the first case, a depth of $10 \mathrm{~mm}$; the liquidity limit corresponds to the humidity of the ground paste at the 10 $\mathrm{mm}$ cone, with two or three markings at the cone of 8-12 $\mathrm{mm}$. In the second case, at a depth of $18 \mathrm{~mm}$, with the conversion of the liquidity limit from the norm of the empirical:

$$
w_{L}=0,0043 \cdot w_{18}^{2}+0,8873 \cdot w_{18}+3,62
$$


where: $\mathrm{w}_{18}$ means the humidity of the ground paste, into which the cone penetrates to a depth of $18 \mathrm{~mm}$, whereby the marks are made at different humidity and the corresponding cone cavity and the dependence graph $\mathrm{f}(\mathrm{w}: \mathrm{h})$ the moisture content of the ground paste corresponding to the cavity $18 \mathrm{~mm}$ is determined. In the carried out research, the liquidity limit $\mathrm{t}$ corresponding the ground paste with the cavity of the cone of $20 \mathrm{~mm}$ was also determined (wherein the assay was performed at different humidity and its corresponding cavity of the cone and the graph $\mathrm{f}$ (in hours) set humidity corresponding conical recess 20 $\mathrm{mm})$. This designation was made with reference to the requirements of the procedure set out in [9].

In the Vasiliev method and cone penetrometer, the soil was placed in a cylinder with a diameter of $5.0 \mathrm{~cm}$ and three layers with air bubbles removed during the compaction. The cone before it penetrated was aligned with the level of the ground in the cylinder. The penetration depth of the cone was recorded to an accuracy of $0.01 \mathrm{~mm}$. In the Casagrande method, the preparation of the ground paste and the method of its laying in the apparatus bowl for eliminating air bubbles and the course of determination of the liquidity limit were carried out according to the procedure of [10].

It should be emphasized that, according to Eurocode 7 [11], valid in Poland since 2010, the method using a cone penetrometer is preferred. The Casagrande method and the national practice continue to be the main method of determining the liquidity frontier before 2010. Therefore, the research problem is relevant for the use of the results of previous research and the need to conduct comparative research on the results of these two most commonly used methods, as pointed out by other researchers [6] and, consequently, on the consistency of the soil [14] (Fig. 1).
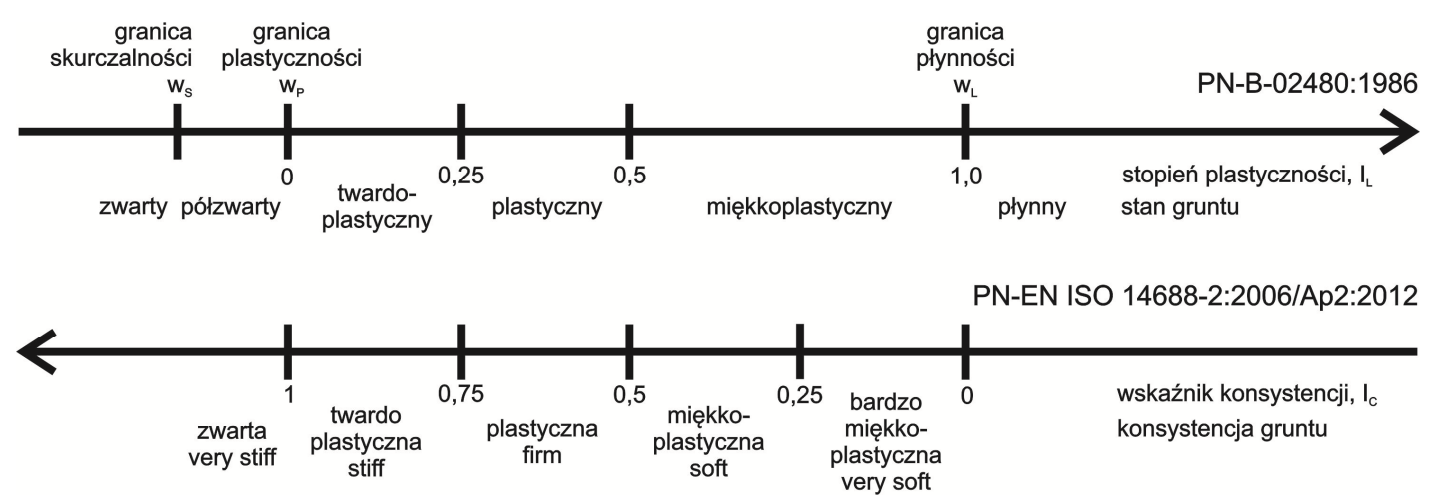

1. Conditions and consistency of fine-grained soils [14]

\section{Research results and their analysis}

Physical properties. The granulometric composition of the studied land was very differentiated (Table 1, Fig. 2). The medium loam sand was the coarse soils with the highest content of sand fraction - about $67 \%$ and with the lowest content of clay fraction - about $9 \%$. The coarse dust was medium cohesive on the low cohesion border with the highest content of particulate matter - over $85 \%$ and slightly higher content of loam fraction - about $11 \%$. The dust was ground cohesive with a high content of dust fraction - $66 \%$ and the highest content of loam fraction - about 21\% (Table 1, Figure 2). Specific skeletal density values and compaction parameters were typical for the relevant types of cohesive soils. The density values of the skeleton were increased from $2,67 \mathrm{~g} \cdot \mathrm{cm}^{-3}$ (sandy loam) to $2,70 \mathrm{~g} \cdot \mathrm{cm}^{-3}$ (dusty loam). 
Tab.1. Geotechnical characteristics of the studied soils

\begin{tabular}{|c|c|c|c|}
\hline Parameter & \multicolumn{3}{|c|}{ Value } \\
\hline $\begin{array}{ll}\text { Fraction content }[\%]: \\
\text { - } & \text { sandy, } 2-0,063 \mathrm{~mm} \\
\text { - } & \text { dusty, } 0,063-0,002 \mathrm{~mm} \\
\text { - } & \text { loam, }<0,002 \mathrm{~mm}\end{array}$ & $\begin{array}{c}66,9 \\
24,4 \\
8,7\end{array}$ & $\begin{array}{c}4,1 \\
85,1 \\
10,8\end{array}$ & $\begin{array}{l}13,1 \\
66,0 \\
20,9\end{array}$ \\
\hline Type of soil acc. to [12] & clMSa & $\mathrm{CSi}$ & $\mathrm{siCl}$ \\
\hline Indicator of variegatedness [-] & 92,9 & 16,3 & - \\
\hline Grain curvature indicator $[-]$ & 3,7 & 3,8 & - \\
\hline Specific density of the skeleton $\left[\mathrm{g} \mathrm{cm}^{-3}\right]$ & 2,67 & 2,68 & 2,70 \\
\hline Maximum skeleton volume density $\left[\mathrm{g} \mathrm{cm}^{-3}\right]$ & 2,01 & 1,77 & 1,69 \\
\hline Optimum humidity [\%] & 11,0 & 13,4 & 19,4 \\
\hline
\end{tabular}

FR A KC JE

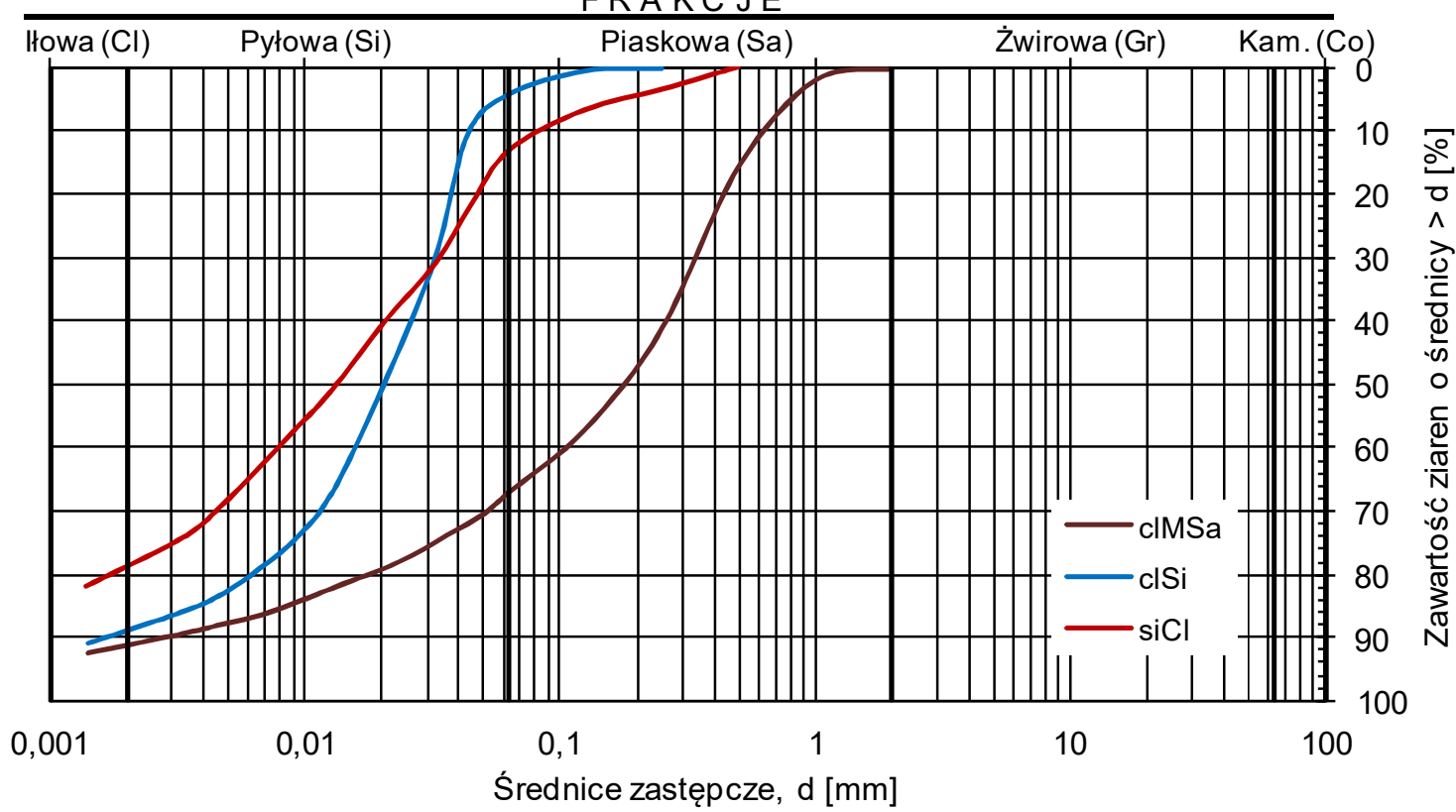

2. Grading curves of the studied soils 
a) Cassagrande's method

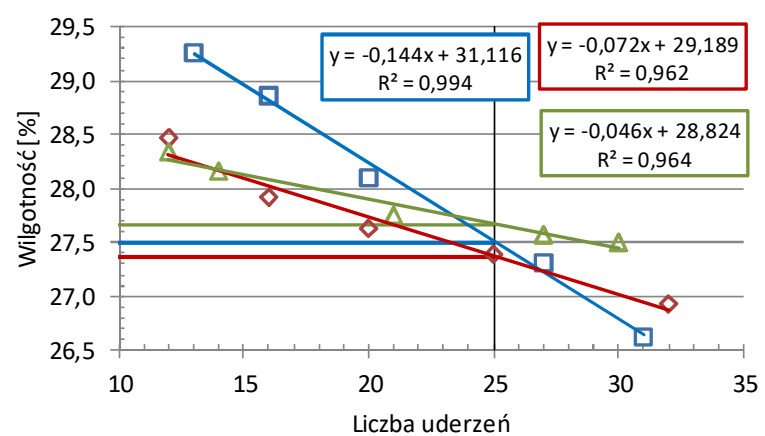

c) cone penetrometer method

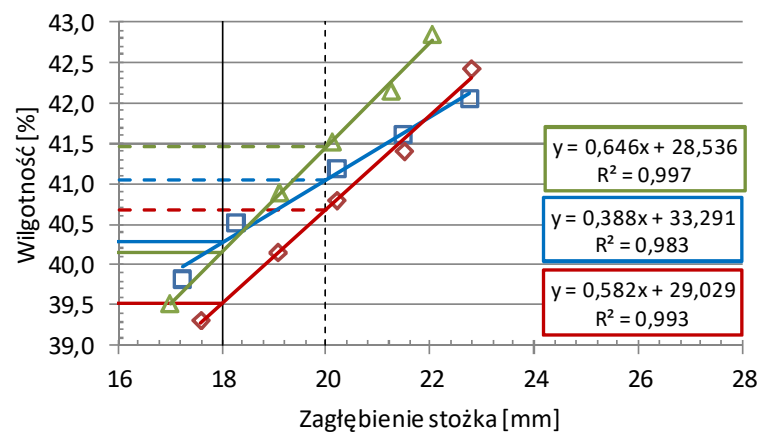

3. The test results in thick dust liquidity limit (CSi)

The values of the maximum skeletal density decreased from over 2.0 (average loam sand) to about $1.7 \mathrm{~g} \cdot \mathrm{cm}^{-3}$ (dusty loam) and the optimum humidity increased from 11 to over $19 \%$.

The boundaries of consistency. The plasticity limit of the examined soil was clearly dependent on the content of the loam fraction and ranged from $11 \%$ for average loam sand to $19 \%$ for thick dust and $22 \%$ for dusty loam (Table 2 ).

Tab.2. Results of soil boundary studies

\begin{tabular}{|c|c|c|c|c|c|c|c|c|c|c|c|c|c|c|}
\hline \multirow{4}{*}{ 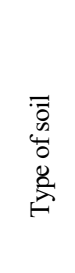 } & \multirow{4}{*}{ 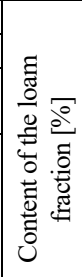 } & \multirow{4}{*}{ 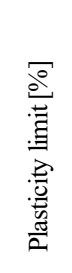 } & \multirow{2}{*}{\multicolumn{4}{|c|}{$\begin{array}{c}\text { Liquidity limit [\%] } \\
\text { Method }\end{array}$}} & \multirow{2}{*}{\multicolumn{4}{|c|}{$\begin{array}{c}\text { Plasticity indicator [\%] } \\
\text { Method }\end{array}$}} & \multirow{2}{*}{\multicolumn{4}{|c|}{$\begin{array}{c}\text { Colloidal activity [-] } \\
\text { Method }\end{array}$}} \\
\hline & & & & & & & & & & & & & & \\
\hline & & & \multirow[b]{2}{*}{ 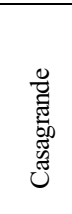 } & \multirow[b]{2}{*}{ : } & \multicolumn{2}{|c|}{$\begin{array}{c}\text { cone } \\
\text { penetrometer }\end{array}$} & \multirow[b]{2}{*}{ 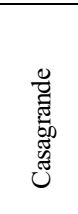 } & \multirow[b]{2}{*}{ : } & \multicolumn{2}{|c|}{$\begin{array}{c}\text { cone } \\
\text { penetrometer }\end{array}$} & \multirow[b]{2}{*}{ 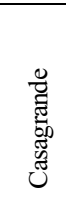 } & \multirow[b]{2}{*}{ 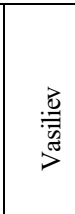 } & \multicolumn{2}{|c|}{$\begin{array}{c}\text { cone } \\
\text { penetrometer }\end{array}$} \\
\hline & & & & & $\begin{array}{c}\text { acc. } \\
\text { to } \\
{[10]}\end{array}$ & $\begin{array}{l}\text { acc. } \\
\text { to [9] }\end{array}$ & & & $\begin{array}{c}\text { acc. } \\
\text { to } \\
{[10]}\end{array}$ & $\begin{array}{l}\text { acc. } \\
\text { to [9] }\end{array}$ & & & $\begin{array}{l}\text { acc. to } \\
{[10]}\end{array}$ & $\begin{array}{c}\text { acc. to } \\
{[9]}\end{array}$ \\
\hline \multirow[t]{2}{*}{$\mathrm{clMSa}$} & \multirow[t]{2}{*}{8,7} & $\begin{array}{l}11,15 \\
10,72 \\
10,92 \\
10,98\end{array}$ & $\begin{array}{l}21,60 \\
21,21 \\
20,93\end{array}$ & $\begin{array}{l}20,29 \\
19,98 \\
20,60\end{array}$ & $\begin{array}{l}26,60 \\
26,44 \\
26,59\end{array}$ & $\begin{array}{l}23,48 \\
23,47 \\
23,47\end{array}$ & $\begin{array}{c}10,66 \\
10,27 \\
9,99\end{array}$ & $\begin{array}{l}9,35 \\
9,04 \\
9,66\end{array}$ & $\begin{array}{l}15,66 \\
15,50 \\
15,65\end{array}$ & $\begin{array}{l}12,54 \\
12,53 \\
12,53\end{array}$ & $\begin{array}{l}1,23 \\
1,18 \\
1,15\end{array}$ & $\begin{array}{l}1,07 \\
1,04 \\
1,11\end{array}$ & $\begin{array}{l}1,80 \\
1,78 \\
1,80\end{array}$ & $\begin{array}{l}1,44 \\
1,44 \\
1,44\end{array}$ \\
\hline & & 10,94 & 21,25 & 20,29 & 26,54 & 23,47 & 10,31 & 9,35 & 15,60 & 12,53 & 1,18 & 1,07 & 1,79 & 1,44 \\
\hline \multirow[t]{2}{*}{$\mathrm{CSi}$} & \multirow[t]{2}{*}{10,8} & $\begin{array}{l}18,91 \\
18,53 \\
19,50 \\
19,18\end{array}$ & $\begin{array}{l}27,50 \\
27,37 \\
27,66\end{array}$ & $\begin{array}{l}26,95 \\
26,60 \\
26,46\end{array}$ & $\begin{array}{l}31,36 \\
32,26 \\
31,68\end{array}$ & $\begin{array}{l}28,10 \\
29,14 \\
28,66\end{array}$ & $\begin{array}{l}8,47 \\
8,34 \\
8,63\end{array}$ & $\begin{array}{l}7,92 \\
7,57 \\
7,43\end{array}$ & $\begin{array}{l}12,33 \\
13,23 \\
12,65\end{array}$ & $\begin{array}{c}9,07 \\
10,11 \\
9,63\end{array}$ & $\begin{array}{l}0,78 \\
0,77 \\
0,80\end{array}$ & $\begin{array}{l}0,73 \\
0,70 \\
0,69\end{array}$ & $\begin{array}{l}1,14 \\
1,23 \\
1,17\end{array}$ & $\begin{array}{l}0,84 \\
0,94 \\
0,89\end{array}$ \\
\hline & & 19,03 & 27,51 & 26,67 & 31,77 & 28,63 & 8,48 & 7,64 & 12,74 & 9,60 & 0,79 & 0,71 & 1,18 & 0,89 \\
\hline \multirow[t]{2}{*}{$\mathrm{siCl}$} & \multirow[t]{2}{*}{20,9} & $\begin{array}{l}22,13 \\
21,81 \\
21,84 \\
21,90\end{array}$ & $\begin{array}{l}44,30 \\
44,64 \\
45,23\end{array}$ & $\begin{array}{l}39,70 \\
40,56 \\
40,20\end{array}$ & $\begin{array}{l}46,34 \\
45,39 \\
46,29\end{array}$ & $\begin{array}{l}41,05 \\
40,67 \\
41,46\end{array}$ & $\begin{array}{l}22,38 \\
22,72 \\
23,31\end{array}$ & $\begin{array}{l}17,78 \\
18,64 \\
18,28\end{array}$ & $\begin{array}{l}24,42 \\
23,47 \\
24,37\end{array}$ & $\begin{array}{l}19,13 \\
18,75 \\
19,54\end{array}$ & $\begin{array}{l}1,07 \\
1,09 \\
1,12\end{array}$ & $\begin{array}{l}0,85 \\
0,89 \\
0,87\end{array}$ & $\begin{array}{l}1,17 \\
1,12 \\
1,17\end{array}$ & $\begin{array}{l}0,92 \\
0,90 \\
0,93\end{array}$ \\
\hline & & 21,92 & 44,72 & 40,15 & 46,01 & 41,06 & 22,80 & 18,23 & 24,09 & 19,14 & 1,09 & 0,87 & 1,15 & 0,92 \\
\hline
\end{tabular}


Liquidity limits were clearly differentiated according to the test method (Table 2, Fig. 3). The smallest differences occurred between Cassagrande and Vasiliev's liquidity limits, and they were about $1 \%$ for average sand and thick dust and $4.5 \%$ for dusty loam, with smaller values obtained from Wasiliev's method (Figure 4) .

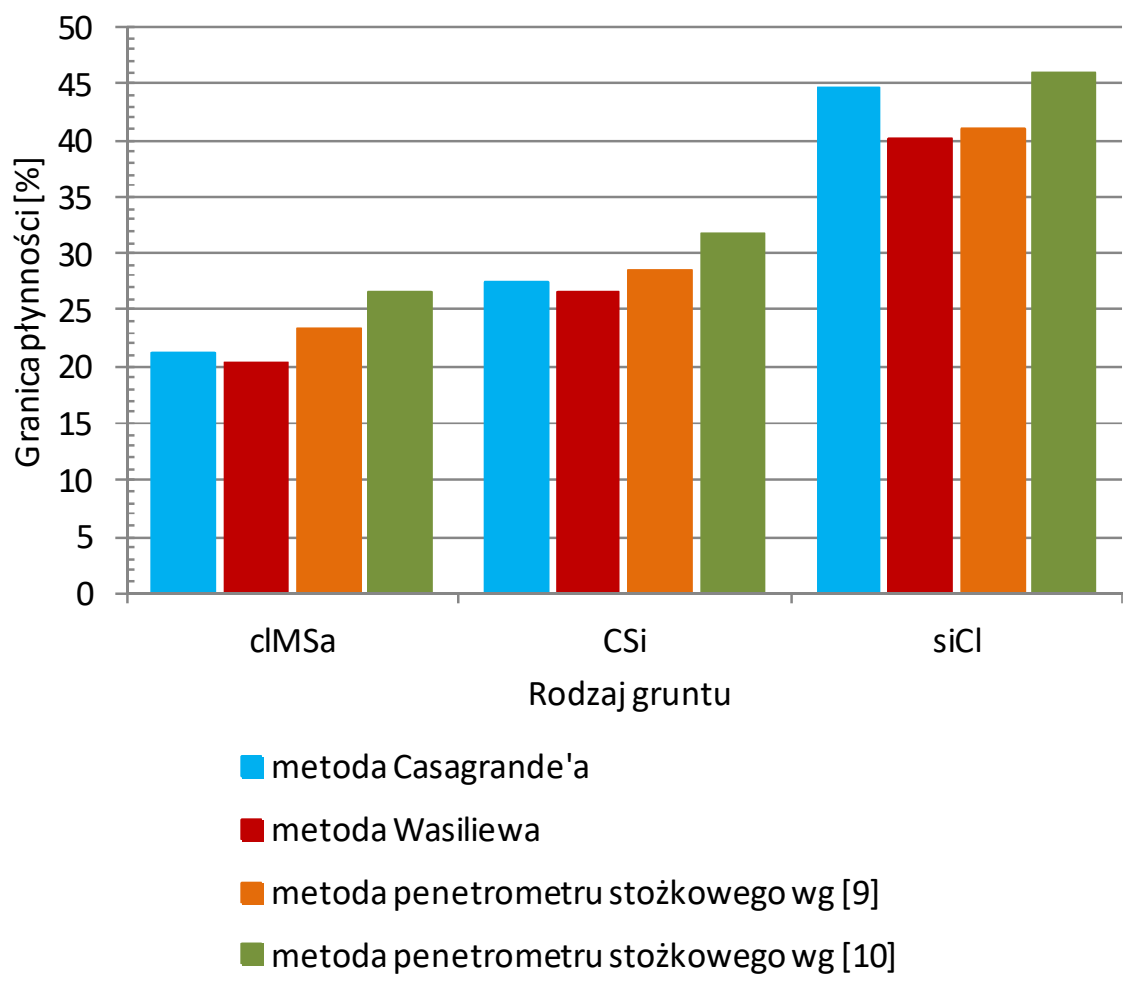

4. Limit values of land's liquidity depending on the test method

c) cone penetrometer method

[9] vs Casagrande method

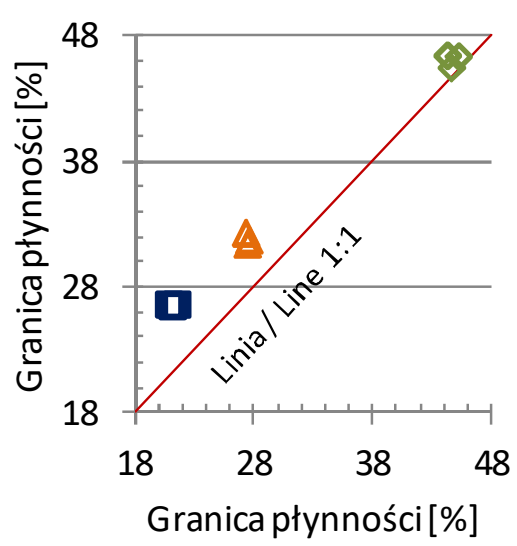

Rodzaj gruntu c) cone penetrometer method [9] vs Vasiliev method

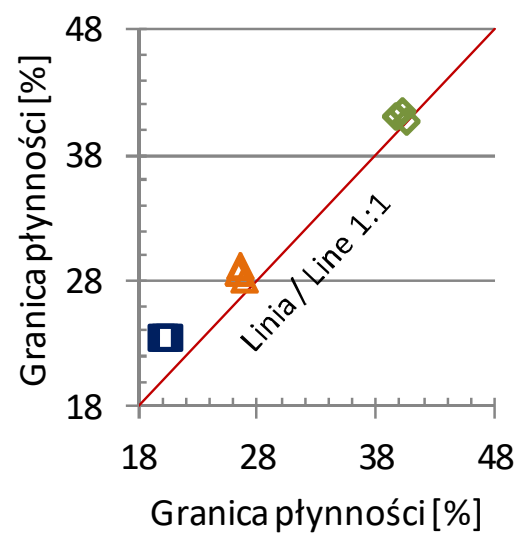

c) cone penetrometer method according to [9] vs cone penetrometer method according to [10]

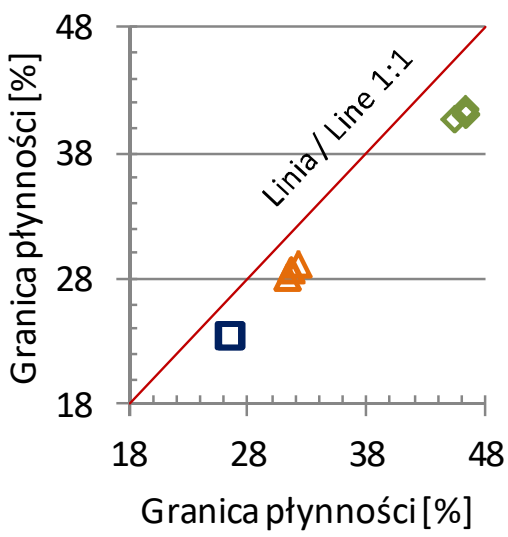

$\square \mathrm{clMSa} \triangle \mathrm{CSi} \diamond \mathrm{siCl}$

5. Comparison of the liquidity limit values of the examined soils by various methods 
Larger differences occurred between Cassagrande's flow limits and cone penetrometer (Fig. 5), with higher values obtained from penetrometer tests and:

- in the case of average loam sand, the mean value of the liquid limit determined by the cone penetrometer at the grounding point at 18 and $20 \mathrm{~mm}$ was higher than the value determined by the Cassagrande method by more than 5 and $2 \%$,

- in the case of thick dust, the liquidity limit values determined by the cone penetrometer at the cavity as above were higher than the Cassagrande value by more than 4 and $1 \%$,

- in the case of dusty loam, the values of the liquidity limit determined by the cone penetrometer at the cavity as above were higher than the value determined by the Cassagrande method by more than $1 \%$, and $3,6 \%$.

By analyzing the results presented above, it can be concluded that the smallest liquidity values were obtained from the Vasiliev method and the largest of the cone penetrometer tests at a cavity in ground paste on $18 \mathrm{~mm}$.

When comparing the results of the liquidity limit test with the cone penetrometer, it should be noted that higher values were obtained from its identification at the cone cavity into a ground paste of $18 \mathrm{~mm}$ : by about $3 \%$ for average loam sand and thick dust and about $6 \%$ for loam dust. The above results show that the liquidity limits calculated according to formula (1) at the cone cavity of $18 \mathrm{~mm}$ are significantly higher than those obtained from the other three methods of determination. Therefore, the results obtained from the above-mentioned method are omitted in further analysis. The results of the Vasiliev method were also omitted, although they are quite close to the results of the other two methods because this method is practically not used in Polish geotechnical laboratories. Because of this, and because the "new" standard [9] prefers the determination of the flow limit by the conical penetrometer, in the case of the cone with the apex $30^{\circ}$ "at the $20 \mathrm{~mm}$ cavity into the ground paste and the Cassagrande method as an alternative, further analysis was made with regard to the results of the tests obtained from the two methods of its determination.

In the case of low / medium cohesion values, the liquidity limits determined by the Cassagrande method were less than $2 \%(\mathrm{clMSa})$ and more than $1 \%(\mathrm{CSi})$ than the cone penetrometer. In the case of cohesive soils ( $\mathrm{siCl}$ ) the value of the liquidity limit determined by the Cassagrande method was greater by more than 3\% than the cone penetrometer method.

The data show that the smaller differences between the liquidity limits obtained from these two different methods occurred in the case of land with a lower content of loam fraction (about 9-11\% - CIMSa and CSi) than with higher content (over 21\% - siCl).

The differences between the values of the liquidity limits obtained by the various methods are reflected in the differences between the values of the plasticity index (Table 2), on the basis of which the division of fine-grained soils has been made according to the "old" classification standard [PN-B-02480: 1986 - see Fig. 1. As can be seen from the values of the yield index shown in Table 2, the same primer can be described as low or medium cohesive (clMSa, CSi) and as medium or coagulant $(\mathrm{siCl})$. As a consequence, the liquidity limit values affect the grade/plasticity index, which determines the consistency of the cohesive soil. With significant differences in the values of these parameters, the soil with a certain moisture content can be classified into different plutonium states or consistency. The greatest discrepancies in the consistency or soil condition are found when the soil moisture is much higher than the plasticity limit. This indicates how important it is to choose the correct method for determining the liquidity limit of cohesive soils.

In order to identify cohesive soils, Cassagrande plasticity sheet (Fig. 6) [3], [13]. Based on the obtained plasticity limit and plasticity index, the cohesive soils were classified as low plasticity soils. The terms in the Cassagrande classification are roughly equivalent to the following [1]: $\mathrm{CH}$ - very coarse soils, $\mathrm{CL}$ - moderately cohesive and compact soils, $\mathrm{MH}$ and ML - less cohesive soils, OL - humus sands and humus dust. 


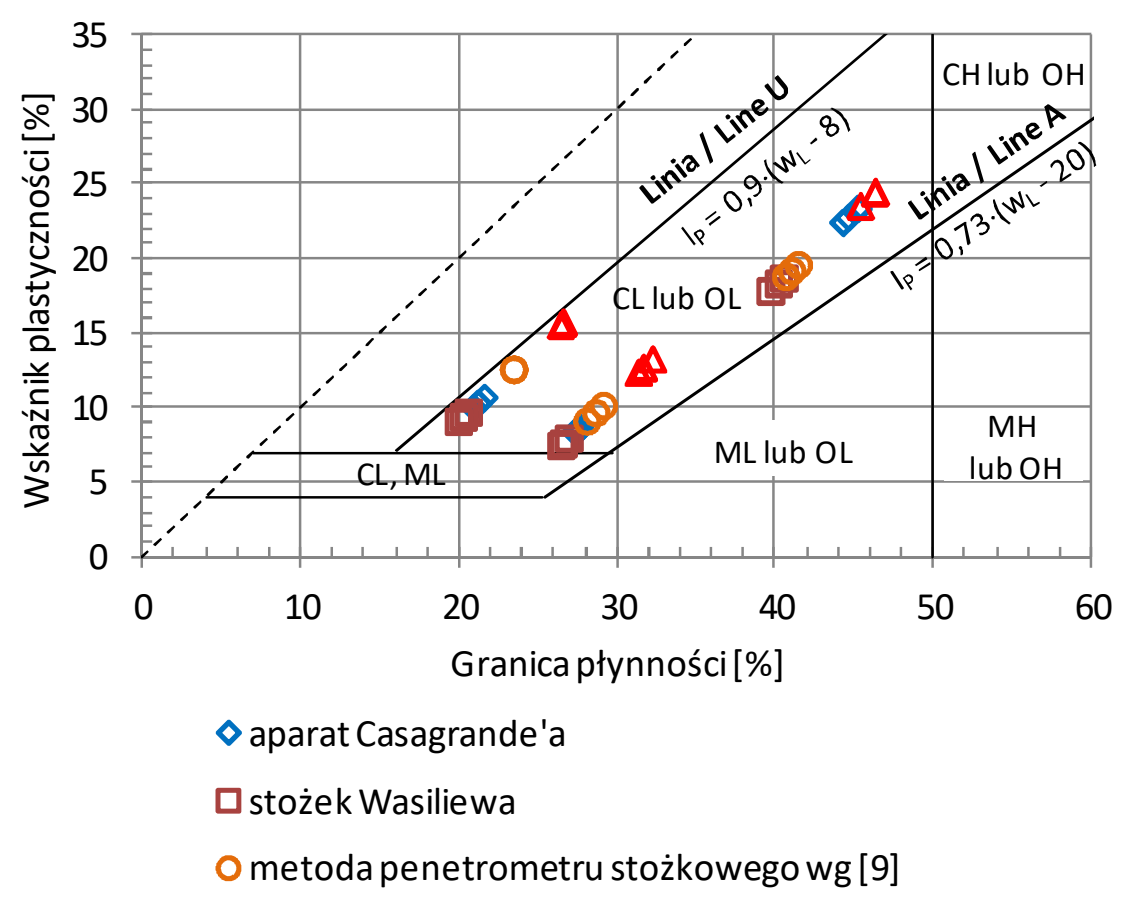

$\Delta$ metoda penetrometru stożkowego wg [10]

6. Examined cohesive soils on the Cassagrande's sheet of plasticity

The practical significance of the consistency limits and the plasticity index is also that they have a content of loam fraction. The more loam particles, the greater is the plasticity index. There is a correlation between the yield index and the content of the loam fraction of the same land [8]. In the case of the examined land, their colloidal activity allows them to qualify for the average active land (Table 2).

\section{Summary}

The values of the liquidity limit of the examined land were differentiated by different methods, which significantly influenced the evaluation of their plasticity and consistency. According to the standard [9], the liquidity limit should be determined by the cone penetrometer, while the alternative method is the Cassagrende method. Studies have shown that:

- in the case of cohesive soils with a content of loam fraction up to $10-11 \%$, the differences between the values of the liquidity limit determined by the cone penetrometer or the Cassagrande method were relatively small and amounted to $1-2 \%$, therefore both methods are correct. Results of Matusiewicz and others [6], however, indicate that in the case of coarse-grained soils with less than $5 \%$ of the clump fraction in which furrows are difficult to perform, it is easier to determine the flow limit of the cone penetrometer than the Cassagrande method,

- in the case of cohesive soils with a content of loam fraction greater than $20 \%$, the differences between the limits of liquidity indicated by the cone penetrometer or the Cassagrande method were slightly higher than in the previous case and were about $4 \%$, as also confirmed by Matusiewicz and others [6], which were carried out on cohesive soils with a content of loam fraction greater than $10 \%$. In these cases, the determination of the liquidity limit can be made by either one or the other method, where the above-mentioned standard prefers the cone penetrometer method. 


\section{Source materials}

[1] Biernatowski K., Dębicki E., Dzierżawki K., Wolski W. Fundamentowanie. Projektowanie i wykonawstwo. Warszawa, Arkady, 1987.

[2] Craig R.F. Craig's soil mechanics. Seventh edition, Spon Press, Taylor\&Francis Group, London and New York, 2004.

[3] Dec T. Mechanika gruntów. Część 1, właściwości fizyczne. Wydawnictwo Wojskowej Akademii Technicznej, Warszawa, 1975.

[4] Grabowska-Olszewska B, Siergiejew J. Gruntoznawstwo. Wydawnictwa Geologiczne, Warszawa, 1977.

[5] Klimek E. Badanie wybranych parametrów geotechnicznych gruntów naturalnych i odpadów przemysłowych - granica płynności. Maszynopis pracy magisterskiej wykonanej w Katedrze Mechaniki Gruntów i Budownictwa Ziemnego Akademii Rolniczej w Krakowie, 1997.

[6] Matusiewicz W., Lechowicz Z., Wrzesiński G. Wyznaczanie granicy płynności metodą Casagrandego i penetrometrem stożkowym. Przegląd Naukowy - Inżynieria i Kształtowanie Środowiska, 2016, 25(3), s. 290-300.

[7] Myślińska E. Laboratoryjne badania gruntów. Wydawnictwo Naukowe PWN, Warszawa, 2001.

[8] Pisarczyk S. Mechanika gruntów. Oficyna Wydawnicza Politechniki Warszawskiej, Warszawa, 1999.

[9] PKN-CEN ISO/TS 17892-12:2009. Badania geotechniczne. Badania laboratoryjne gruntów. Część 12: Oznaczanie granic Atterberga. Polski Komitet Normalizacyjny, Warszawa.

[10] PN-B-04481:1988. Grunty budowlane. Badania próbek gruntu. Polski Komitet Normalizacyjny, Warszawa.

[11] PN-EN 1997-2:2009. Eurokod 7. Projektowanie geotechniczne. Cz 2: Rozpoznanie i badanie podłoża gruntowego. Polski Komitet Normalizacyjny, Warszawa.

[12] PN-EN ISO 14688-2:2006. Badania geotechniczne. Oznaczanie i klasyfikowanie gruntów. Część 2: Zasady klasyfikowania. Polski Komitet Normalizacyjny, Warszawa.

[13] PN-EN ISO 14688-2:2006/Ap.2:2012. Poprawka do Polskiej Normy: Badania geotechniczne. Oznaczanie i klasyfikowanie gruntów. Część 2: Zasady klasyfikowania. Polski Komitet Normalizacyjny, Warszawa.

[14] Sulewska M. Nowa klasyfikacja gruntów. Przegląd Naukowy - Inżynieria i Kształtowanie Środowiska, 2016, 25(3), s. 333-346.

[15] Wiłun Z. Zarys geotechniki. Wydawnictwo Komunikacji i Łączności, Warszawa, 2000. 